\title{
Review: St. John's wort is more effective than placebo for treating depressive disorders
}

Linde K, Mulrow CD. St. John's wort for depression. Cochrane Review, latest version 09 Jul 1998. In: The Cochrane Library. Oxford: Update Software.

\section{Question}

Are extracts of St. John's wort (Hyperiplacebo and standard antidepressants in patients with depressive disorders?

\section{Data sources}

Studies were identified by searching MEDLINE (from 1983), PsycLIT (1987 to 1997), EMBASE/Excerpta Medica (from 1989), the clinical trial registry of the Cochrane Depression, Anxiety, and Neurosis Group, the Cochrane Complementary Medicine Field, and the private database Phytodok (Munich); by scanning bibliopharmaceutical companies.

\section{Study selection}

Studies were selected if they were randomized controlled trials (RCTs) that compared St. John's wort with placebo or other antidepressants for depressive disorders. Studies with physiologic outcome measures only were excluded. cum perforatum) as effective and safe as graphies; and by contacting authors and

\section{Data extraction}

2 reviewers extracted study characteristics and resuits and assessed the quality of each study.

\section{Main results}

27 studies (2291 patients) met the inclusion criteria. 17 trials were placebo controlled. Follow-up ranged from 2 to 12 weeks in 26 studies \{mean 5.5 wk); 1 study had an unknown length of follow-up. More patients responded to St. John's wort than to placebo (14 studies, $\left.\{P<0.001\}^{*}\right)$ (Table). No differences in responder rates occurred for $S t$ John's wort compared with low-dose antidepressants (5 stadies, $\left.\{P=0.79\}^{*}\right)$ (Table). Fewer side effects occurred with St. John's wort than with low-dose antidepressants $\{28 \% \text { ws } 45 \%, P=0.002\}^{*}$.

\section{Conclusions}

St. John's wort is more effective than placebo for depressive disorders. Responder rates do not differ for St. John's wort and low-dose antidepressants; side effeus are less common with St. John's wort.

Sotires of funding: National thatitute of $\mathrm{Ar}$ thritis and Musctiloskeletal and Skin Disetres and Karl und Veronica Cartens-Stifung.

For correspondence: Dr: K. Linde, Munchener: Modell Centre for Complententary Medicine. Researb, Technial University/Ludwig-Manmillans-University, Kaiserstrasse 9, Monid. 80801, Genmany. FAX 49-89-393484.

*Numbers calculated from data in article.

Abstract and Commentary also published in ACP Fournal Club. 1999;130:60; and in Evidence-Based Mental Kealth. 1999 May. A modified version of this abstract appents in Euddente.Based Natsing. $1999 \mathrm{Jul}$.

Responder rates for St. John's wort (SJW) vs control in depressive disorderst

\begin{tabular}{lcccc}
\hline $\begin{array}{l}\text { Comparison at a mean } \\
\text { follow-up of } 5.1 \mathrm{wk}\end{array}$ & \multicolumn{2}{c}{ Weighted event rates } & RBI (95\% CI) & NNT (CI) \\
\cline { 2 - 5 } & SJW & Control & & \\
\hline SJW ws placebo & $56 \%$ & $25 \%$ & $140 \%(70$ to 239) & $4(3$ to 6$)$ \\
\hline $\begin{array}{l}\text { Comparison at a mean } \\
\text { follow-up of } 5.6 \text { wk }\end{array}$ & & & RBR (C) & NNH
\end{tabular}

SJW vs antidepressants $\quad 51 \% \quad 52 \% \quad 3 \%(-12$ to 16$) \quad$ Not significarit

$+\mathrm{RBR}$ = relative benefit reduction. Other abbreviations defined in Glossary; RBI, RBR, NNT, NNT, and Cl calculated from data in article.

†The trials were heterogeneous; therefore, a random-effects model was used.

\section{Commentary}

Many physicians are skeptical of "alternative" remedies and respond to claims made by advocates of these remedies with calls for more evidence--specificaliy, evidence from RCTs. This meta-analysis by Linde and Mulrow reports the results of 27 such. trials comparing $S t$. John's wort with either placebo or active treatments. It suggests that St John's wort is more effective than placebo and is as affective as low-dose tricyclic antidepressants (TCAs) in the treatment of depression. The mechanism of action seems to be similar to that of conventional antidepressants-inhibition of reuptake of monoamines (1).

The authors point to the small sample sizes, brief followmup periods, and inadequate doses of conventional antidepressants used in many (but not all) of the trials reviewed. How serim ous are these concerns? It is instructive to contrast the St John's wort triats with those con- paring more conventional antidepressants: TCAs and selective serotonin retptake inhibitors (SSRIs). In a previous review (2), we found that the median sample size of TCA and SSRI trials was 64 patients. For the equivalent trials comparing St.John's wort with active treatment, the median sample size was 101 . This suggests that these trials may be of higher quality than those of more conventional treatments. This point shotild reassure readers who may be concerned that many of the trials are published in unfamiliar German-language joumals. Similarly, although low doses of TCAs were often used in the St. John's wort $\mathrm{RCTS}, 25 \%$ of trials comparing SSRIs and TCAs also used low doses. Further work siggests that the necessity of prescribing high-dose TCAs may have been exaggerated (3). Hence, although bigger and better trials would be welcome, it is unfair to condemn St. John's wort on this basis.
Although this review gives some sipport for St. John's wort, some questions remain unanswered. Considerable uncercainty exists about dosage--these trials had big differences in prescribed doses. Herbal remedies are often poorly regulated and tend not to receive the same postmarketing surrelatively little may be known abour possible rare adverse effects.

$$
\begin{array}{r}
\text { Matthety Hotopf, MBBS, MS } \\
\text { Institute of PSychinth } \\
\text { London, England, UK }
\end{array}
$$

References

1. Muller WE, Rossol R. J Geratr Psyctipl try Neurol. 1994;7:S63-4.

2. Hotopf $M$, Lewis $G$, Notmand $C$. $\int \mathrm{Epi}$ demiol Community Health. 1997;51:3548.

3. Trindade $\mathrm{E}, \mathrm{M}$ non $\mathrm{D}$. Ottawa: Cand a Assessment, 1997 Aug. Report $3 \mathrm{E}$. veillance as conventional treatments. Thus, Coordinating Office for Health Technolos 